\title{
THE PORTRAIT OF THE MAN IN LITERATURE: A CRITICAL STUDY OF THE TREATMENT OF MAN IN LITERARY WORKS WITH SPECIAL REFERENCE TO THE SELECTED WORKS OF JONATHAN SWIFT AND ALEXANDER POPE
}

\author{
Seyedeh Zahra Nozen (Ph D) ${ }^{1}$, Bahman Amani (Ph D) ${ }^{2}$, Majid Zarei (MA) ${ }^{2}$ \\ ${ }^{1}$ (Corresponding Author)Department of English, Amin Police Science University \\ ${ }^{2}$ Department of English Literature, University of Malayer \\ nozenzahra@gmail.com
}

\begin{abstract}
The nature of man has always been under the close consideration of many philosophers and thinkers throughout history. The challenge has raised many questions about human nature; what is man? what features distinguish man from other animals? and more importantly, what is the conception of human nature? is it inherently good or evil? is it affected by environment? is it selfish or social? does man have free will or not? can human nature be changed? how can man change it? Through searching to find answers for all these questions, many scholars in various fields of study have always been attempting to define human nature. On one side, this study provides different theories of human nature in philosophy, religions, psychology and more significantly, literature. On the other side, the core focus of the study is on Jonathan Swift and Alexander Pope, two English satirists of eighteenth century, who define the nature of man from their own point of views in their most arguable works about human nature, Gulliver's Travels and An Essay on Man. In a nutshell, this study aims to understand the concept of human nature in the selected works of Jonathan Swift and Alexander Pope by comparing to all the definitions and theories of human nature.
\end{abstract}

Keywords: Man, Philosophy, Nature, Jonathan Swift, Alexander Pope

\section{INTRODUCTION}

What is man? what sort of being is he? is man a rational being? is he an autonomous creature who functions as an individual or is he a social creature? does man possess reason? If so, what is reason? what about emotions and feelings? is man free or controlled by a force? what core characteristics does man have? is man good or evil? In the history of thought, many philosophers and thinkers have always tried to answer all these questions which concern human nature. For religious thinkers, spiritual natures are the most important feature of human nature. In western philosophy, Plato and Aristotle, the classical Greek philosophers, examine human nature. Plato believes that man is a rational creature who has the ability to reason and that man's nature is connected to his soul. For Aristotle, both body and soul contribute to the essence of man's nature. In fact, they distinguish man from other animals because of his unique quality, reason. Rene Descartes expands Plato's idea about human nature and describes man as a thinking soul. On the contrary, based on what Darwin discusses through his theory, the logic of evolution, man is not above other animals, but it is only the product of nature which has been developed through various circumstances. Unlike Plato and Aristotle, David Hume argues that man is more influenced by feelings than by reason. According to him, reason is the slave of passions and emotions.

The nature of man is a significant conception in literature as well and many literary figures have argued about it through ages. Most literary works in the first half of the eighteenth century, known as the Augustan age, are focused on political and social issues mainly because of the Enlightenment thought of the period. The goal of an artist, according to Alexander Pope, is the attempt to explain the true nature of man by understanding human. Le Bossu emphasizes on the importance of studying man: "Man being the chief and the most noble of all the Effects which God produc'd, and nothing being so proper, nor more useful to Poets than this Subject" (Le Bossu 3). The focus is on reason in both Jonathan Swift and Alexander Pope's works 
as a distinctive feature of human nature. Many critics after Gulliver's Travels attempt to find out Swift's intentions in writing this work. Swift stresses on Human ignorance and vanity. It is because of man's vanity which he considers himself superior to other animals. On the contrary, there is Descartes who considers man superior to other animals concerning man's reason. Swift compares man to the beasts in his satires and does not consider man above other beasts. Swift in Further Thoughts on Religion states:

Lions, bears, elephants and some other animals are strong or valiant and their species never degenerates in their native soil, except they happen to be slaved or destroyed by human fraud: but men degenerate every day, merely by the folly, the perverseness, the avarice, the pride, the treachery or inhumanity of their own kind. (Herbert 268)

Swift is against Descartes' idea accepting that animals are irrational brutes while men are rational brutes. But he does not accept that man is superior to other animals because he knows stupidity and foolishness are worse and lower than bestiality. Modern critics of Alexander Pope focus on man and examine this aspect of Pope's works from various perspectives. New critical readings of Pope generalize his satires as harsh attacks on human vices. Most believe that Pope's works convey some ideological dimensions. For instance, Brean Hammond claims:

The character of Pope's ideology is that of a family-based, Christian aristocrat or landed gentleman, implacably opposed to the elite of, as he believed, corrupts financiers, bankers and brokers who governed the country. (Hammond 61)

Pope's An Essay on Man, as a work on human nature, receives much admiration by many critics. Voltaire in his Lettres Philosophiques admires Alexander Pope and states The Essay on Man "appears to me to be the most beautiful didactic poem, the most useful, the most sublime which has ever been composed in any language" (Voltaire 35). Maynard Mack also considers An Essay on Man as a truth to mankind and argues:

... the controlling theme of the Essay on Man as a poem is a theme of constructive renunciation. By renouncing the exterior false Paradises, man finds the true one within. By acknowledging his weaknesses, he learns his strengths. By subordinating himself to the whole, he finds his real importance in it. (Mack 78)

\section{THEORY}

Man is a term which has been under a close consideration of a wide range of disciplines such as philosophy, religion, anthropology, psychology, biology, politics and more significantly, literature. The term, man, has posed a not-easy-answerable question in all ages for thinkers, philosophers and even the layman alike. Accordingly, a numerous number of definitions of man have been revealed through the history. In order to achieve a comprehensive understanding of the concept of human nature, all the realms of study should be taken into consideration including religious, psychological, literal and philosophical point of views.

Three main religions which will be discussed on the concept of human nature are Islam, Buddhism and Christianity. In fact, religious theories about man state his place in the universe and also trying to define what makes a human-being different from other living things.

\section{Man in Islam}

According to Islam, man himself is not capable of defining man and his characteristics because man's understanding of himself is influenced by many things including his social situation, his cultural position and his interests. Thus, God is the only one who can define the man and the perfect humanity. In Islam, man is an honored creature. As God in the holy Quran says "We have honored the children of Adam and carried them on earth and in the sea and provided to them the good sustenance. And we made them better than many of what we created" (qtd. in Maulana 13). Based on Islam, man is the greatest of all creatures as he possesses freewill and the power of thinking. Therefore, a perfect man in Islam is a person who "has attained perfection in Islam: a perfect believer is one who has attained perfection in his faith" (Maulana 33). "The Islamic man possesses the power of reason, of ratio which divides and analyses, but his mental faculties are not limited to reason" (qtd. in Maulana 13 Nasr 2). As a matter of fact, the spiritual world is at 
the core of Islamic thoughts in contrast to the conception given to the modern man who is considered as an earthly creature.

Opposite to Islam in which man is born pure and innocent and upon reaching adolescence man is responsible for all his actions and must choose between right and wrong, human nature in Buddhism is based on ignorance and sentient beings. According to Buddhism, there are three important characteristics of existence: constant change, selflessness and suffering. The first quality of existence is related to the impermanency of this world in which everything is changing constantly and nothing in this world is fixed. The present condition of man is determined by past actions and all his thoughts, senses, beliefs and notions are out of his control and completely depend on the situation which finally cause suffering for human. Buddhism aims to free man from the ignorance that is at the root of all this suffering. The second characteristic of existence is directly related to the conception of human nature as Buddhists believe that there is no self (no atman) and realizing the self is an illusion which leads to compassion - the most important Buddhist virtue. Normally, Buddhism "rejects the existence of self" (Stevenson and Haberman 65 ) and they often propose a specific concept of "personhood".

The theory of human nature described by Christianity is mostly based on reason and freewill. As Genesis 1:26 suggests that "mankind is made in the image of God, to have dominion over the rest of creation" (Stevenson and Haberman 74). According to Christianity, human is a rational being and has the freedom of choice.

Probably the most crucial point in the biblical understanding of human nature is the notion of freedom, conceived of as the choice between obedience to God's will, faith in Him, and love for Him - or disobedience, faithlessness, and pride and also the necessity for choice between obedience and disobedience, good and evil. (Stevenson and Haberman 75)

According to Christianity, humans are made in the image of God; "And God said, let us make man in our image, after our likeness" (qtd. in Stevenson and Haberman 75). Humans are special in comparison with other creatures. Humans must choose between good and evil which their eternal salvation depends on this choice. Humans possess their faith and heart in the process of selection of good and evil. The emphasis on the human's faith refers to the goodness of human nature. God has created us "so that we fulfill the purpose of our life only when we love and serve our Creator." Thus, obedience to God is the most important element in Christianity. But, sometimes we use the freedom given by God in a wrong way and choose evil rather than good.

\section{Man in Philosophy}

Philosophy interprets man and his various aspects and qualities in a comprehensive manner. It makes a connection between individuals and the society. In addition, it helps man understand the importance of human and the world. In order to reach the basic concepts of human nature in Eastern philosophy, Confucianism in China would be the best example to be discussed the related issue. Considering the ancient doctrines of Eastern philosophy about the concept of mankind would be, inevitably, under the influence of Confucius, the Chinese thinker. The Analects is his main work which consists of Confucius's basic ideas and beliefs about man. Confucius believes that "Man lives in a moral world. Morality is part of the very fabric of the universe; there is something ultimate and transcendent about ethical conduct" (qtd. in Stevenson and Haberman 26). Morality is the only thing that should be followed, according to Confucius, by human beings in life. Confucius seems to have a very positive view toward the nature of man and his only aim is to help man become a sage. In spite of believing that man is potentially a sage, he reaches the belief that "a sage is a very rare being" (qtd. in Stevenson and Haberman 28). He also clarifies that human being has a "freedom of will" (qtd. in Stevenson and Haberman 29). Even though man cannot control his own destiny, man is free to choose between morality and immorality.

Western philosophy of human nature begins with the ancient Greek thinkers. Plato believes that by the use of reason and intellectual faculty man can find the Good. He adds that the knowledge of the Good is enough for virtue. Based on Plato's theory, there is both material body and immaterial mind which is considered as soul. According to him, it is only the soul that knows the forms. Then, he concludes that mind and soul are 
much important than the senses. So it is reason that must rule all human's doings and behaviors. According to Plato, mostly expressed in his Republic, human is defined as a social animal that enjoys rationality. Plato, actually, attempts to consider human nature with reason which is an opponent element to the physical aspect of human being, the body, in contrast to his pupil, Aristotle who believes both body and soul are inseparable and indivisible in human's nature.

Aristotle's idea of 'truth' is totally different from that of Plato. Aristotle believes that truth is primarily discovered by senses while Plato states that truth is primarily discovered by reason. Aristotle clarifies:

All men by nature desire to know. An indication of this is the delight we take in our senses; for even apart from their usefulness they are loved for themselves; and above all others the sense of sight... The reason is that this, most of all the senses, makes us know and brings to light many differences between things... (Aristotle, Aristotelian Metaphysics 74)

Every being is a mixture of form and matter. One cannot separate these two from one another. For Aristotle, it does not make sense to talk of soul or mind without a body because the essence of a person is intertwined with his matter. Aristotle considers man as a social and political creature. He believes that man can only reach his full development if he exists in the society.

Thomas Aquinas (1225 - 1274), the Scholastic philosopher, is the one whose teachings became the philosophy of the Roman Catholic Church. Aquinas's philosophical views are explained in his most important work which is called Summa Theologiae. In fact, he defines man in his work as

Man, like any other being, has naturally an appetite for the good; and so if his appetite inclines away to evil, this is due to corruption or disorder in some one of the principles of man. (Aquinas 941)

Thomas Aquinas attempts to regenerate Aristotle's beliefs and synthesizes it with Christian beliefs, although many religious people in the church reject Aristotle. Like Aristotle, Aquinas also believes that knowledge starts with the senses. Man has a rational aspect which consists of perception, reason and free will. Like what Aristotle believes, Aquinas considers man's soul as the most important part of human nature which is not a substance. But he claims that there is a link between soul and body as man derives meaning through his mind and soul and acts decisively upon it. Unlike following thinker, Rene Descartes, who believes that man's rational mind, imposes meaning on the world, Aquinas says that man gets meaning first through his senses and then he acts upon it.

Rene Descartes (1596 - 1650), French scientist and philosopher, is the first one who formulated the first modern version of mind-body dualism. According to Descartes, human nature is composed of a material body and an immaterial soul. The material body can be studied by science in contrast to the immaterial soul which can never be studied by science. He also explores that the immaterial aspect can exist without the body but material aspect cannot exist without mind. As he says in one his most famous quotations: "I think therefore I am" (Descartes 84). He expresses that human being is an immaterial mind and the essential nature of the mind is its conscious ability to think.

Thomas Hobbes is best known for his political philosophy in his masterpiece, Leviathan (1651). As a matter of fact, the rise of science in $17^{\text {th }}$ century changed the world. This scientific revolution indeed influenced the theories of human nature as well. Totally different from the Greek philosophers, the other philosopher who emphasized about human nature and proposed dissimilar sights in defining man is Thomas Hobbes. Thomas Hobbes explains in his most famous work, Leviathan, that human activity as working is much like a machine. He believes that only matter exists and there is no matter and soul together in humans. He, therefore, argues a completely materialistic view of human being in which human nature is exclusively materialistic. Hobbes claims that man is greatly selfish and only desires food, wealth, power and lots of other things just for himself. Man is always in war with each other to achieve these supplies. His famous motto is that "man is wolf to the man" (Hobbes 105) which clearly indicates his point of view toward human nature. 
David Hume is well known for his philosophical empiricism and skepticism. Hume considers philosophy as the inductive science of human nature. Hume is actually an empiricist, one who believes that knowledge comes from sense experience. Reason mostly talks of the relationships but sense experience tells us about how the world works. He states that the notions and thoughts of man are derived from impressions. According to Hume, there is no self or soul but only consciousness which is a sort of mental state. In contrast to what Hobbes believes, Hume believes that self-interest is not merely the only human's motivation in his behaviors.

In his Discourse on the Origin of Inequality, Jean-Jacque Rousseau clarifies that it is the effect of society and various circumstances which lead to the savage nature of humans and the tendency toward self-interest in their actions. Man, in Rousseau's perspective, is considered as a peaceful creature without aimless violence. Rousseau accepts Hobbes's theory of self-interest but he mentions that it would happen only when it is induced by a specific reason or aim. According to Rousseau, man is, thence, naturally good and peaceful being ruled by their reason and wisdom. Rousseau believes that human being is innately good and the only reason of evilness of man is the corrupting influence of society. He reasons that civilization or "noble savage" is the most important element on the vices of man. Like Romantic thinkers, Rousseau believes that the nature is good. Although reason is the coral concern of most of the philosophers, to Rousseau, passions are more important than reason.

\section{Man in Literature}

One of literature's central concerns is to define man's nature. In fact, literature has always attempted to express the ways of humanity and a great understanding of man and his behaviors. For instance, William Shakespeare's plays can be considered as the best examples of pieces of literature which provide great definitions on human nature. Most of Shakespeare's plays are about the downfall of a character. This flaw which arises within the character, indeed, comes from his nature. Shakespeare introduces the characters such as Macbeth, Hamlet and Othello as humans who have never been existed in order to reach some hidden aspects of human nature. For instance, William Shakespeare's Macbeth follows the ideas of the English philosopher Thomas Hobbes on the nature of man. Hobbes believes that man is a selfish creature and is constantly at a war with man. Accordingly, this situation produces brutish people. In the tragedy, Macbeth and Lady Macbeth think only of themselves and even use other people to reach their own purposes as Macbeth uses Duncan to gain power and consequently, the throne of Scotland. There are also some other authors that have considered the nature of man as the coral concept of their works such as William Golding and Edward Said.

William Golding is one the major writers who takes the conception of human nature into his consideration. The Lord of the Flies and Rite of Passage are the most important works of Golding which mostly discuss the concept of man. William Golding has a completely dark and pessimistic view of human nature and society. William Golding fought in World War II and this was sufficient for him to witness the darkness of humanity. He, in fact, finds man as an evil.

World War II was the turning point for me. I began to see what people were capable of doing. Anyone who moved through those years without understanding that man produces evil as a bee produces honey, must have blind or wrong in the head. (Golding, The Lord of the Flies)

Edward Said have revolutionized the concept of humanity in the late twentieth century. He believes that it is power that allows you to define other humans as they wish. Thereafter, Said publishes another work under the title of Humanism and Democratic Criticism. He expresses his clear thoughts and notions toward humanity in this work. He attempts to articulate a new humanism under the category of 'Secular criticism'. Said believes that far from the fights and wars, cultures can interact and make benefits for human being which is the idea of humanistic culture.

... the hopefulness, the faith in a humanistic culture of shared understanding, the role criticism must play in using that understanding to bring about fruitful interaction, the distrust of undeconstructed terms, of collective passions, of acrimony and aggression - of all, that is, which hinders or thwarts the advance of humane societies. (Said 14) 
He talks of humanism and believes that "Humanism is the only - I would go so far as saying the finalresistance we have against the inhuman practices and injustices that disfigure human history" (Said 23)

\section{ALEXANDER POPE}

Alexander Pope, as a man, chooses to be more virtuous and moralist than being a strict religious man. Pope believes that God has created man rational, logical and thoughtful but it is the man himself who willingly turns a blind eye to the right way. The main motive of Pope's writings is to reform moral principles and the improvement of mankind. Most critics find Pope's works, especially his satires, as an attack on human vices and his stupidity. Pope emphasizes on the trivial things which human cares about them in spite of morality in The Rape of the Lock and The Dunciad. In fact, Pope tries to represent his philosophical ideas toward man as he calls it discussing "general Map of Man" (Pope, An Essay on Man).

\section{Man in An Essay on Man}

An Essay on Man has been considered one of the most controversial works of the Enlightenment. It addresses the nature of human in different aspects and the role of humankind in the system which God has created. In general, An Essay on Man deals with man both as an individual and as part of community. Pope touches upon several philosophical attitudes in his poems many of which are discussed in previous chapter. It is about the fallen man and depicting the ways which he can seek his own salvation. He proposes that man is an imperfect and evil creature because of his constrained intellectual capacity. Humans must accept their position in the "Great Chain of Being" (Pope, An Essay on Man 16) which is something between evils and angels. Man possesses reason, the quality which distinguishes him from other animals. For Pope, man is considered as an imperfect creature, although he possesses reason. Like Jean-Jacque Rousseau, Pope believes that by nature everything is good and benevolent. Pope believes that human's pride leads him to corruption and evilness. In a broader sense, An Essay on Man is compartmentalized into two sections. The first section proposes the question; what is man? and the second section argues man and culture. The work also deals with reason and the misapplication of it by man. So similar to what Muslims believe through their religious doctrines, man possesses freewill and can choose between good and evil. Man is responsible for everything he does whether he uses his reason in a right way or a wrong way. The other similarity between Pope's ideas and Islam is that man is not perfect and has limited knowledge but he can reach to perfection through the faith to the Only God.

Epistle I shows the order of the universe and man's place in the universe and subsequently describing improvements and betterment of human nature and society by accepting the universe as a prefect and ordered world. By nature, the world is an order of "strong connexions, nice dependencies... gradations just" (Pope, An Essay on Man 30-31). In the first lines of this epistle, Pope addresses his friend to "leave all meaner things" (Pope, An Essay on Man) and care not for trivial things like material things and be more virtuous and moral. Like David Hume, Pope has been considered a moralist that man should follow moral principles as the only important issues in man's life. And unlike Hobbes, Pope is not a materialist. For Hobbes, only matter and body exist while Pope believes that reason is of the great importance which guides man to be virtuous and moral.

Epistle II discusses man as an individual and the relationship between man and God. Man is a rational animal, in spite of having emotions and passions. It examines the psychological factor of humankind as well. It is argued that humans are governed by emotions and passion but it is the reason which guides man. Rationality can be considered as the strong link between the classical thinkers of Greek and Renaissance to French philosopher Rene Descartes' famous saying 'je pense, donc je suis' (I think, therefore I am) and Alexander Pope. Pope discusses that the nature of man comprises two parts: self-love and reason. Passion, as one of the forms of self-love, defines human nature besides his reason on the other aspect of his creation.

Two principles in human nature reign;

Self-love to urge, and reason, to restrain;

Nor this a good, nor that a bad we call,

Each works its end, to move or govern all

And to their proper operation still,

Ascribe all good; to their improper, ill. (Pope, An Essay on Man Lines, 53-58)

Submit Date: 10.01.2018, Acceptance Date: 23.02.2018, DOI NO: 10.7456/1080MSE/124

Research Article - This article was checked by Turnitin

Copyright (C) The Turkish Online Journal of Design, Art and Communication 
Although, there was still no progress in psychology and Sigmund Freud and Carl Jung were not born yet, Alexander Pope examined self and unconsciousness. According to Pope's philosophy, self-love and reason are not opposing principles. He believes that self-love produces virtues and reason brings the human virtues and behaviors regulation:

God loves from whole to parts: but human soul

Must rise from individual to the whole.

Self-love but serves the virtuous mind to wake. (Pope, An Essay on Man)

Emphasizing on human nature, Pope like Plato and Aristotle states that man should have "a proper study of mankind" in order to understand the place of man in the universe:

Know, then, thyself, presume not God to scan;

The proper study of mankind is man. (Pope, An Essay on Man)

Epistle III discusses the man in the society and the relationship between man and the government, the social system and religion. Like Aristotle, Pope examines man both as an individual and in the society. They look at man as a rational creature and his reason is the only device to reach the truth in life. Both believe that there is a direct connection between man as an individual and the society as a whole which effect on one another in different ways. Man is an animal as he has brutality but he can rise above them with the help of a distinguishable nature, reason.

Epistle IV considers happiness, particularly, true happiness which is attainable through virtue and right doings. Happiness is considered as the ultimate aim of humankind as Pope says in the first lines of the epistle:

Oh, happiness, our being's end and aim!

Good, pleasure, ease, content! whate'er thy name. (Pope, An Essay on Man)

Man cannot find happiness in wealth and social or political status except for virtue. Pope then argues that happiness is real in a social context, not in isolation. The virtuous man is always happier than the evil man. Pope here agrees with Aristotle who believed that man is a social animal and he can reach his full development if he exists in the society. Pope adds that happiness is actually the especial reward for the virtuous man:

What nothing earthly gives, or can destroy,

The soul's calm sunshine, and the heartfelt joy,

Is virtue's prize: A better would you fix?

Then give humility a coach and six. (Pope, An Essay on Man)

Rene Descartes declares in Discourse on Method that "Good sense is the most evenly distributed commodity in the world" (Descartes 51). Pope's aim is to show how man can achieve happiness by having a proper view of the world, society and at last, himself.

Know, then, this truth (enough for man to know)

Virtue alone is happiness below. (Pope, An Essay on Man)

\section{Man in The Dunciad}

In general, The Dunciad is a poem on dullness. Pope attempts to explore folly and stupidity of man in this harsh satire. Although, Pope attacks individuals as his own enemies in The Dunciad, the work is not aimed to criticize a special person. Generally, he attacks and denounces dullness and stupidity of all human-being. Pope believes that there is an absolute corruption and chaos in the society in terms of morality and ethics:

Lo! thy dread empire, Chaos, is restored; 
Light dies before thy uncreating word:

Thy hand, great Anarch, lets the curtain fall;

And universal darkness buries all. (Pope, The Dunciad 653-656)

Dulness is the main character in the story and by Dulness, indeed, Pope means man. Pope defines Dulness in the second version of his book in a footnote:

Dulness here is not to be taken contractedly for mere stupidity, but in the enlarged sense of the word, for all Slowness of Apprehension, Shortness of Sight or imperfect Sense of things. It includes Labour, Industry and some degree of Activity and Boldness: a ruling principle not inert but turning topsy-turvy the Understanding and inducing an Anarchy or confused State of Mind. (Pope, The Dunciad in Four Books)

Pope actually represents the dark side of human nature. Pope describes the reign of Dulness which dominates all over the world. Miseducation is one of the main elements of immorality which results in dullness. In fact, it is through the education which man becomes wise and moral. According to Pope, if a man is far from logic and reasonability, he would definitely fall into the meanest place of humanity. Pope talks mostly about the vanity of humankind. It shows the elimination of reason and sense. Logic is limited. Wit has been totally forgotten. Stupidity and meaninglessness are bold and morality has no place. "A brain of feathers and a heart of lead..." (Pope, The Dunciad Book II 44) As a whole, Pope's first concern in The Dunciad is moral reformation. Cibber is an evil man in the story and undoubtedly it shows the evilness of man. Pope believes that stupidity and immorality is universal and man has the responsibility for all the corruption. As a conclusion, the image that Alexander Pope presents from man and humanity in Dunciad is the image of a human-being who acts without reason and follows a ridiculous and foolish logic. According to Pope, wisdom, knowledge and education are the only ways to free humans from the darkness of ignorance.

\section{JONATHAN SWIFT}

Swift has been widely considered as a misanthropist by many thinkers and critics because he shows man as a savage animal. Swift assumes that there is a big gap between the reality and the ideal condition of man and society by looking at the degeneration of man. Swift discusses on the unattainable perfection by man, an ideal vision which man strives to reach it. Swift's view of human nature is the impossibility of ideal, although man possesses complete reason, he is far from ideal and perfection. The animality of human is at the center of his works, particularly Gulliver's Travels and A Modest Proposal. Some correspondence by Jonathan Swift reveals his perspective to the nature of man and his definition of man. In the most important one, in 29 September, 1725, in a letter from Jonathan Swift to his friend, Alexander Pope, Swift states his idea toward human nature and defines man as a creature with reason:

... the chief end I propose to myself in all my labors is to vex the world rather [than] divert it... I have ever hated all Nations profession and [communities] and all my love is towards individuals... Principally I hate and detest that animal called man, although I heartily love John, Peter, Thomas and so forth... I have got Materials towards a Treatise proving the falsity of that Definition animal rationale; and to show it should be only rationis capax. Upon this great foundation of Misanthropy the whole building of my [Travels] is erected. (Williams 102-3)

In the letter, there is a harsh and terrible attitude toward man. It shows the misanthropy side of Swift's works such as Gulliver's Travels. Swift accepts that his work is on the "great foundation of Misanthropy." But his hatred of man is not that harsh because Gulliver returns home and accepts his resemblance to the Yahoos. Besides, Swift asserts that man has the potentiality to change. Swift disagrees with the conception of animal rationale (man is a reasoning creature) and gives credit to the conception of rationis capax (man has the ability to reason).

\section{Man in Gulliver's Travels}


Generally, Gulliver's Travels is a controversial satire on humanity. Degeneration of the man is the main concern as Gulliver calls that "continual degeneracy of human nature, so justly complained in all ages" (Swift, Gulliver's Travels 210). Swift's main aim in writing his satires is to "vex the world rather than divert it." In Swift's age, it was widely believed that a rational man is a complete man. At the same time, Descartes' theories about the use of reason were also common as well as Locke's theories on natural religion. Swift worships reason, but opposes excessive pride in reason. Alexander Pope agrees with Swift in which our society is filled with self-love and pride. Swift believes that man possesses reason but he is far from being completely rational.

Gulliver's first voyage is to Lilliput where people in small size live there. In many ways, Lilliput resembles England. More generally, it is a satire on the human tendency to abuse politics in order to achieve their own purposes. Man's pettiness and pride are two concepts which are attacked in the first book. The Lilliputians follies resemble the follies of man. In Lilliput, Gulliver sees small minds. Lilliput has been a country which is unsafe to be morally good as Lilliputians try to kill Gulliver which represents their cruelty. The people of Lilliput are treacherous, malicious and cruel.

Left by his shipmates, Gulliver finds himself in Brobdingnag, a land of giants. All things in the Brobdingnag are much larger than ones in the real world. But, they are not only large in size; they are also big in morality in contrast to the first book where Lilliputians are small in size and morality. In fact, we have a reverse in the size in this book. Brobdingnag is a sort of moral Utopia. There is virtue and good will. Swift follows Plato's ideal society in which reason and rationality are the most important aspect of human nature.

As his third trip, Gulliver visits Laputa, a flying land full of wizards and magicians. The land is run by scientists and philosophers. Although the land seems like a utopia in scientists' point of view, it is far from civilization, according to Swift. Swift depicts that humanity and ethics are much less concerned than different sciences such as chemistry, physics and mathematics. The third voyage of Gulliver shows Swift's disdains on scientific theories and ideas which in no way help the virtue and morality of man. Man's false use of reason is the main reason of corruption in morality and humanity.

The most controversial book is the fourth book, where Gulliver faces the rational horses, the Houynhmhms and the Yahoos, irrational ones. In this book, there is the strongest and bitterest critique of man. Swift talks of reason and proposes the reason as the essence of man. After Gulliver encounters the Yahoos, he recognizes the similarity of man and the Yahoos. Gulliver detests them because they remind him of his society he has lived before. The horses are reasonable and rational while the Yahoos lack reason and have nothing except for passions and emotions. The Yahoos are savage and symbolizes humans for they behave immorally. On the other hand, the Houyhnhnms symbolize the ideal man. Gulliver discovers that the rational animals are horses and the beasts are men. He says that

The beast and I were brought close together, and our countenances diligently compared, both by master and servant, who thereupon repeated several times the word yahoo. My horror and astonishment are not to be described, when I observed, in this abominable animal, a perfect human figure. (Lund 276)

The Yahoos are the representative of debased human and the Houyhnhnms as the ideal form of rationality and humanity. The Houyhnhnms speaks in a special language. They do not have words like war, lie and deception. There is no love in the relationships, but they never commit adultery, they are never brutal, they have no word to describe evil. They are full of virtue, benevolence and friendship. In fact, because of their rational and logical behaviors, they live in a utopia which Swift endeavors to present the world for humans as well. In this respect, Swift wants to prove that reason is the only quality which can lead man to morality. According to Samuel Holt Monk, "the horses are as Swift's ideal for man and the Yahoos as the ideal for what we are" (Monk 103). Yahoos, the half-animal humans, are similar to what Rousseau says about noble savage. Like Rousseau, Swift believes that man has become bestial through characterizing Yahoos. Humans are given "some small pittance of reason... no other use than by its assistance to aggravate our natural corruptions and to acquire new ones which Nature had not given us" (Lund 195). Gulliver finds out that men are "Yahoos in Shape and Disposition, perhaps a little more civilized, and qualified with the Gift of Speech, but making no other use of Reason, than to improve and multiply those Vices" (Lund 376). 
Man is said to be the worst of all creatures, first of all because as a Yahoo he is by nature, malicious, treacherous, libidinous, cowardly, and insolent; and second, because he has presumed to tyrannize over his fellow-animals and make them his slaves who are his superior. (Bullitt 86)

Undoubtedly, Gulliver's Travels can be considered as one of the most powerful attacks which are against man's follies and stupidity. The book expresses Swift's anger at the cruelty and stupidity of man. As his deepest examination of human, Swift argues that man should be governed by reason as the most crucial element of human nature.

\section{Man in A Modest Proposal}

In this bitter and ironic satire, Swift defends Ireland in this work and proposes an ironic solution for the poverty of Ireland of his time. A Modest Proposal is an example of Juvenalian satire which targets social vices and also individual follies. A Modest Proposal examines man largely on his nature as inhumane and hard-hearted creature. Man has no value according to Swift's perspective. Swift shows his disgust of man as they have become like an animal. Swift believed that God created man rational and reasonable, but he is not so as he has freewill. As a whole, A Modest Proposal has been written as a reaction to a social and political problem of his time. And Swift is going to propose a solution to the problem. Lee Perlman discusses about the detachment of rationality of man from passion and emotion in A Modest Proposal:

The pretense is that moral thought can be reduced to practical calculation. Swift criticizes the moral weakness of mothers who have abortions or commit infanticide, which he describes as a horrid practice, while himself posing the more economically sound solution of selling children for food. The joke, of course, is that, in earnestly proposing a solution to monstrosity, the author casually proposes one far greater. It is the reduction of moral thought to nothing more than calculating rationality that is the true source of the writer's cruelty - and perhaps of the peculiar track record of modernity for the same, in spite of its Enlightenment. (Perlman 108)

In fact, the work is a social mirror. It is a harsh satire on the hopelessness situation of Irish people, but can be expanded for all humankind. The satire gives the readers freedom to talk about issues which are difficult to express in the society. In this impoverished state, Swift expresses sympathy and the need for a solution. Swift believes that humanity needs to be increased in the society. There must be no war, no quarrel and no injustice. In a nutshell, A Modest Proposal is a political satire, but it concerns all people. It made readers to think at the end about human values. It is full of humanitarian concerns. Swift only shows his detestation of human vice in his satires.

\section{CONCLUSION}

The conception of human nature has always been under the consideration of many thinkers in various fields of study. They all have tried to define man and his nature in order to understand what man is and what distinguishes him from other animals. There are many similarities and differences between the theories of human nature among thinkers and philosophers which were discussed through the previous chapters by focusing on the specific definitions of the conception of man presented by Jonathan Swift and Alexander Pope. Plato looks at man as a body that is dominated by his soul. Aristotle defines man as a rational animal. William Shakespeare in his plays portrays man a foolish mortal who has deficiencies as tragic flaws. According to Aquinas, much like Aristotle, man is a political animal, but his true happiness is in the eternal world after death. For Thomas Hobbes, man is a smarter animal than other animals. They do not differ in kind of intelligence, but in degree. Sensation and knowledge differ in kind. He pictures the best sort of living for man through Leviathan. Nietzsche waits for the super man. Karl Marx believes that human nature is made by the progression of history. Sigmund Freud considers man as a creature of internal inflict. Freud is a materialist who considers mental states including unconsciousness as dependent elements of brain states. According to the first idea of Freud's theory of human nature, he believes in determinism in psychology meaning that humans have no free will. Although he also believes that we sometimes make rational decisions.

Most of the great writers of the age of reason in the eighteenth century spent much of their time concentrating on the unreasonableness of man. Philosophers of the period like John Locke knew that only 
man is capable of reason. But, how can man be so fool in spite of having reason? "... from the point of view of Reason, all humans (inasmuch as to be human is to be in some degree a deformation of the pure ideal) are in some way caricatures." And also "Human beings are already caricatures, to the eye of a Swift. There needs no added meddling of art" (Hammond 133). Through several satires, Swift attempts to criticize the behaviors and acts of man in a society. The main idea is the animality of man as depicted in both Gulliver's Travels and A Modest Proposal. Misuse of reason which leads to moral corruption is the central argument of Swift's satires. Swift's satires depict human cruelty, corruption and rational idiocy.

On the other hand, in An Essay on Man, Alexander Pope aims to examine the nature of man in the universe as an individual and a part of society. Pope also acknowledges man's possession of reason: "A voice there is, that whispers in my ears, 'Tis reason's Voice" (Whitney 9). As it is believed in the philosophy as well that it is for the reason that Aristotle separates man from the beasts as Samuel Johnson calls it "the great distinction of human nature" (Rambler 162). According to both Jonathan Swift and Alexander Pope, unfortunately, man makes little use of this quality which he possesses. "Pope celebrates certain people who manifest the virtues of true reason." Thus in the Moral Essays Pope defers to the Augustan belief that "the scattered actions of men ultimately make for unity and harmony in society" (Hammond 152). According to Pope, there is a limitation of reason for man as a guide to moral conduct.

\section{REFERENCES}

Hammond, Brean. "Pope amongst the Satirists", 1660-1750. Horndon, UK: Northcote House Publishers, 2005.

Davis, Herbert, "Further Thoughts on Religion, The Prose Works of Jonathan Swift", London: Oxford, 1938.

Mack, Maynard, editor, "An Essay on Man: The Twickenham Edition of the Poems of Alexander Pope", vol. 3. New Haven: Yale University Press, 1950.

Wahiduddin Khan, Maulana, "Islam, The Voice of Human Nature", Goodword Publication, 1989.

Stevenson, Leslie and Haberman, David, "Ten Theories of Human Nature", New York: Oxford University Press, 1998.

Aristotle, "Aristotelian Metaphysics", edited by W. D. Ross, Oxford University: Clarendon Press, 1983.

Aquinas, Thomas, "Summa Theologiae", trans. Fathers of English Dominican Province, New York: Benziger, 1948.

Hobbes, Thomas, "Leviathan”, Oxford: Clarendon Press, 1909.

Pope, Alexander, "The Dunciad in Four Books", Valerie Rumbold, ed. Longman Press: 1999.

Pope, Alexander, "An Essay on Man”, ed. Henry Morley, London: Oxford Press, 1891.

Descartes, Rene, "Discourse on Method, in the Philosophical Works Of Descartes", vol. 1, trans, Elizabeth S. Haldane and G. R. T. Ross, Cambridge University Press, 1911.

Said, Edward, "Humanism and Democratic Criticism", Palgrave UK, 2004.

Bullitt, John M. 'Jonathan Swift and the Anatomy of Satire', Cambridge: Harvard University Press, 1966.

Lund, Roger D. “Jonathan Swift's Gulliver's Travels: A Sourcebook”, New York: Routledge, 2006. 